\title{
Sellar Mixed Germ Cell Tumor
}

National Cancer Institute

\section{Source}

National Cancer Institute. Sellar Mixed Germ Cell Tumor. NCI Thesaurus. Code C155811.

A mixed germ cell tumor that arises from or adjacent to the sellar region. 